\title{
Lactic Acid Bacteria Fermentation of High Protein Feeds: Effect Storage Time Aerobically and Turmeric (Curcuma Longa) Addition on Quality of Fermented, Fortified and Protected Protein Feed
}

\author{
R Abdiwibowo $^{1}$, Z Bachruddin $^{1,2}$ and A Kurniawati ${ }^{1}$ \\ ${ }^{1}$ Laboratory of Nutritional Biochemistry, Faculty of Animal Science, Universitas of Gadjah Mada, Jalan Fauna \\ No: 3, Kampus UGM, Bulaksumur, Yogyakarta, indonesia, 5528 \\ *Corresponding author. Email bachrudin@ugm.ac.id
}

\begin{abstract}
Protein feed is an essential nutrient for livestock production, but it is easily spoiled if not appropriately handled. This study aimed to determine the effect storage time aerobically and turmeric (Curcuma longa) addition on chemical and physical properties on fermented, fortified, and protected protein $(2 \mathrm{~F} 2 \mathrm{P})$ as a feed additive. The high protein feeds as concentrate protein fermented by lactic acid bacteria, tempeh starter, and fermented ethanol starter. The fermentations were incubated at room temperature anaerobically. Meanwhile, protected and fortified of fermented concentrate protein was done by carbohydrate, oil, mineral addition, and heated. This study runs two treatments, the first treatment was the addition of $3 \%$ turmeric and without the addition of turmeric, and the second treatment was difference storage time aerobically at 0 and 20 days and room temperature. Storage time that to long causing feed damage because fungal and bacterial contaminants, so that necessary addition antioxidant ingredient like a turmeric to extend storage time. Each treatment had six replications. The variables observed included organoleptic observations consisting of (color, odor, texture, and fungal contaminants). Chemical quality consists of $\mathrm{pH}$ value, Aflatoxins, proximate analysis (dry ingredients, organic matter, crude protein, and fat). Physical parameters discussed descriptively. The result of this study showed that addition of turmeric had significant effect $(\mathrm{P}<0.05)$ in maintaining on the content of organic matter, crude fat, crude protein, aflatoxin, and FFA contamination, but the addition of turmeric did not effect on $\mathrm{pH}$ and organic matter content (P> 0.05). The addition of 3\% turmeric can maintain chemical and physical quality, as well influence in reducing aflatoxin contamination from protein fermented, protected, and fortified in storage for 20 days, so that the quality of feed maintained during storage.
\end{abstract}

Keywords: Lactic Acid Bacteria, Protein, Storage, Turmeric.

\section{INTRODUCTION}

Feedstuff that has high protein content is a perishable feed if it is stored in room temperature aerobically for long storage, and it is necessary to make a treatment, e.g., lactic acid fermentation processing. By this fermentation process is expected to maintain the quality of protein feed by lowering the $\mathrm{pH}$ due to lactic acid accumulation. Low $\mathrm{pH}$ can inhibit microorganisms and extend the shelf their life. This fermentation can also change the macro protein molecules into micro protein molecules to get easily digested feed, which has superb quality.

Anaerobic fermentation technology can maintain nutritional quality, namely of protein feed, while the technology is expecting in reducing production costs. On of anaerobic fermentation is a fermentation process that involves lactic acid bacteria (LAB). This LAB can maintain feed products by enriching biological value through increasing lactic acid production as its main product.

As a result of the fermentation process, the feed has an acidic $\mathrm{pH}$. This acidic condition can prevent pathogenic microorganisms so that the shelf life of feed will be longer [1]. The quality of fermented protein feed can be maintained with treatment, for example, the treatment of adding preservatives. Turmeric is an herbal plant that is usually used as a 
preservative because turmeric contains curcumin compounds that can inhibit the growth of pathogenic bacteria [2].

Turmeric is a medicinal plant in the form of shrubs and is perennial plants spread over the tropics. The main benefits of turmeric are as traditional medicinal ingredients, raw materials for herbal and cosmetic industries, and as a feed additive, so that turmeric functions as an antiinflammatory, antioxidant, and anti-microbial [3].

This study aimed to determine the effect of turmeric as a preservative on fermented protein

\section{MATERIAL AND METHOD}

\section{1 Extraction of curcumin}

Twenty grams of turmeric flour mixed with $200 \mathrm{ml}$ of $95 \%$ ethanol and soaked for $2 \times 24$ hours. The results of macerated turmeric powder then filtered using Whatman No.42 paper. Ethanol was evaporated by aerating. The precipitate from the ethanol extraction is then extracted again using 200 $\mathrm{ml}$ of distilled water. The formed sediment then evaporated with a Rotary Vacuum Evaporator at a temperature of $\pm 400^{\circ} \mathrm{C}$ with a speed of $120 \mathrm{rpm}$.

\subsection{Protein feed fermentation}

Preparation and determination of each inoculant of Lactic acid bacteria (LAB, Aspergillus niger, tape yeast, and, tempeh yeast. LAB used as a starter is a mixture of LAB that isolated, selected, and identified in the Biochemical Nutrition Laboratory. The supply of raprima tempeh starter and NKL ( $\mathrm{Na}$ sources during storage cause Feedstuff that has high protein content is a perishable feed if it is stored in room temperature aerobically for long storage so that necessary addition antioxidant ingredients for quality of the feed can be maintained. The quality of feed observed included physical (colour, smell, texture and mold contamination), chemical quality (dry ingredients, organic matter, crude protein, and fat), and for observation during storage.

Kok Liong) tape obtained from the market, and production of $A$. niger in same laboratory. The number Starters used for the fermentation process tape yeast: $2 \times 10^{6} \mathrm{CFU} / \mathrm{ml}$, tempeh yeast: $2.9 \times 10^{6}$ $\mathrm{CFU} / \mathrm{ml}$, A. niger $1.4 \times 10^{7} \mathrm{CFU} / \mathrm{ml}$, and $\mathrm{LAB}$ mixture: $3.05 \times 10^{6} \mathrm{CFU} / \mathrm{ml}$.

The composition of the protein feed was Distiller's Dried Grains with Soluble (DDGS), soybean meal, molasses, water and vitamin, and minerals. Ingredients of DDGS and soybean meal steamed for 15 minutes. Then all the ingredients were mixed and fermented for one week anaerobically. Fermented feed ingredients were then fortified with the addition of rice bran, tapioca flour, salt, and premix and protected by heating, the composition and proportion of fermented, fortified and protective protein feed ingredients presented in Table 1.

Table 1. Composition of feed ingredients for the fermented fortified and protected protein feed.

\begin{tabular}{ccc}
\hline No & Feedstuff & Amount \\
\hline 1 & DDGS & $2 \mathrm{~kg}$ \\
2 & soybean meal & $1 \mathrm{~kg}$ \\
3 & Molasses & $90 \mathrm{gr}$ \\
4 & Water & $1400 \mathrm{ml}$ \\
5 & Starter LAB & $90 \mathrm{gr}$ \\
6 & Starter yeast Tape & $90 \mathrm{gr}$ \\
7 & Starter yeast Tempe & $90 \mathrm{gr}$ \\
8 & A. niger & $90 \mathrm{gr}$ \\
\hline
\end{tabular}

\subsection{Treatments and Observation}

The results of fermentation, fortification, and protection of protein feed then had two kinds of treatments, the first treatment was without the addition of turmeric and the second treatment was with turmeric addition $3.0 \%(\mathrm{w} / \mathrm{w})$ then stored during 20 days and observed changes during storage. Each treatment has six replications. Variables observed include. Each treatment had six replications. The variables observed included organoleptic observations consisting of (color, odor, texture, and fungal contaminants). Chemical quality consists of $\mathrm{pH}$ value, Aflatoxins, proximate 
analysis (dry ingredients, organic matter, crude protein, and fat.

\subsection{Data analysis}

Data analyzed using factorial analysis. If there were variable differences because the treatment, then

\section{RESULT AND DISCUSSION}

\subsection{Physical quality of Fermented, Fortified and Protected Protein (2F2P)}

The results of this study showed that the color of protein feed that was fermented, fortified and protective $(2 \mathrm{~F} 2 \mathrm{P})$ produced the right color because there was no color change in storage for 20 days. This result that the addition of turmeric can maintain the color 2F2P. [4] states that the color of good fermented feed was the color of the feed close to the color before fermentation.

The aroma of $2 \mathrm{~F} 2 \mathrm{P}$ produced due to the addition of turmeric and without turmeric at the beginning of the storage 0 days was good because it had a sourer and sweeter aroma like the aroma of the result silage feed. However, in the storage of P2FP was for 20 days, the turmeric addition made the aroma more acidic than without the turmeric addition. The reason for that it was because the
Duncan's multiple range test (DMRT) employed. Organoleptic tests including color, texture, aroma, and fungal contaminants were analyzed descriptive.

long storage time aerobically can cause spoiled. Unsuccessful silage would be made rotten and rancid aroma due to mold contamination [5].

The condition of the $2 \mathrm{~F} 2 \mathrm{P}$ texture on storage for 20 days has occurred clumping. The texture of PF2P becomes lumpy due to storage due to contact with air so that microorganisms will grow. Texture of the clotted feed as a result of contact with air so that the activity and growth of microorganisms run well [6].

The amount of mold in $2 \mathrm{~F} 2 \mathrm{P}$ due to the addition of turmeric herbs was less on the 20th-day storage compared to without the addition of turmeric. Curcumin has a group of polyphenol compounds that can act as antibacterial by inhibiting the thiolase enzyme so that disulfide bonds in bacteria not formed so that secondary protein structures are damaged and denatured [7]. Physical quality of Fermented, Fortified and Protected Protein (2F2P) during storage can be seen in Tabel 2.

Table 2. Physical quality of Fermented, Fortified and Protected Protein (2F2P) during storage

\begin{tabular}{cccc}
\hline Variabel observed & Storage time & \multicolumn{2}{c}{ Treatment } \\
\cline { 3 - 4 } & & $\begin{array}{c}\text { Curcumin } \\
\text { addition }\end{array}$ & $\begin{array}{c}\text { Without curcumin } \\
\text { addition }\end{array}$ \\
\hline Colour & 0 & 5 & 4 \\
Smell & 20 & 4 & 3.4 \\
Texture & 0 & 5 & 5 \\
& 20 & 4 & 5 \\
Mold contamination & 0 & 5 & 3 \\
& 20 & 5.6 & 5 \\
\hline
\end{tabular}

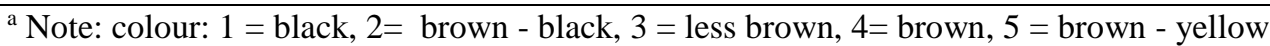

${ }^{\mathrm{b}}$ Smell : 1 = bad odour, 2 = un odour, $3=$ less acid, $4=$ acid, $5=$ fresh acid

${ }^{\mathrm{c}}$ Texture $: 1=$ slimy - clot, $2=$ clot, $3=$ less clot, $4=$ small clot, $5=$ fresh not clot

${ }^{\mathrm{d}}$ Fungi : 1 = high content of mold 2 = plenty mold, $3=$ less mold, $4=$ small mold, $5=$ fresh

\subsection{Chemical quality of Fermented, Fortified and} Protected Protein (2F2P)

The addition of turmeric had a significant effect on dry matter content (DM) $(\mathrm{P}<0.05)$. DM content of samples that were added by turmeric has high levels of $73.58 \pm 0.6$ because turmeric contains antimicrobial compounds that can inhibit bacterial growth so that carbohydrate and protein compounds do not break down into energy. Turmeric contains antibacterial which is useful in inhibiting bacteria, especially spoilage bacteria and while curcumin also inhibits the growth of bacteria that can break down carbohydrate proteins into energy [8].

The content of organic matter (BO) $2 \mathrm{~F} 2 \mathrm{P}$ in turmeric treated samples had no significant effect during storage $(\mathrm{P}>0.05)$. Turmeric has not been able to influence the changes in $\mathrm{BO}$ because the presence of microbes can be able to change $\mathrm{BO}$ for growth. Decreasing in organic matter occurs due to decomposition of organic matter as a substrate for the growth of microorganisms. Another factor in the process of decomposition of organic matter can produce water, so $\mathrm{BO}$ content reduces [9]. 
The effect of turmeric addition had a significant effect $(<0.05)$ on the crude fat content in $2 \mathrm{~F} 2 \mathrm{P}$ and by this addition had a higher crude fat content than without the addition of turmeric. Higher levels of turmeric will reduce the water content. Decreasing water content as a result of increasing levels of turmeric can prevent the oxidation reaction and fat hydrolysis so that the addition of turmeric can maintain levels of crude fat [10]. Curcumin can act as a radical scavenger compound and curcumin has been known to contain antioxidants which have a role as a radical antidote. In addition to curcumin, it also acts as a catalyst for the formation of hydroxy groups [11].

The addition of turmeric has a significant effect $(<0.05)$ on the crude protein content of $2 \mathrm{~F} 2 \mathrm{P}$. The addition of curcumin can increase or maintain crude protein levels. [12] states that curcumin can bind to cell proteins and contain anti microorganism compounds that can inhibit microbial growth so that microbes cannot utilize proteins as nutrients for growth. Compounds in turmeric can act as antioxidants that can reduce oxidation reactions so that protein changes for protein synthesis by microbes can be suppressed. The addition of turmeric can maintain crude protein levels during storage. Storage for too long will cause a reaction that causes free radicals to act with proteins. [13] states that a free radical tends to react first with antioxidants compared to other molecules because antioxidants are very easily oxidized. Chemical quality Fermented, Fortified and Protected Protein (2F2P) during storage can be seen in Tabel 3.

Table 3. Chemical quality of Fermented, Fortified and Protected Protein (2F2P) during storage

\begin{tabular}{|c|c|c|c|c|}
\hline \multirow[t]{2}{*}{ Chemical composition } & \multirow{2}{*}{$\begin{array}{c}\text { Storege } \\
\text { time }\end{array}$} & \multicolumn{2}{|c|}{ Treatment } & \multirow{2}{*}{ Avarage } \\
\hline & & Curcumin addition & Without curcumin addition & \\
\hline \multirow{3}{*}{ DM $(\%)$} & 0 & $73.58 \pm 0,6$ & $72,53 \pm 0,41$ & $73,85 \pm 0,17$ \\
\hline & 20 & $71.92 \pm 1.6$ & $70.551 \pm 1.01$ & $71.33 \pm 1.5$ \\
\hline & Total & $72.75 \pm 1.49$ & $71.54 \pm 1.27$ & \\
\hline \multirow{3}{*}{$\mathrm{OM}(\%)^{\mathrm{ns}}$} & 0 & $93.57 \pm 1.35$ & $93.66 \pm 1.39$ & $93.61 \pm 1.30$ \\
\hline & 20 & $93.33 \pm 1.16$ & $93.63 \pm 1.30$ & $93.49 \pm 1.19$ \\
\hline & Total & $93.46 \pm 1.21$ & $93.64 \pm 1.28$ & \\
\hline \multirow{3}{*}{$\mathrm{CF}(\% \mathrm{DM})$} & 0 & $22.57 \pm 1.32$ & $21.81 \pm 1.29$ & $22.19 \pm 1.256$ \\
\hline & 20 & $21.78 \pm 1.073$ & $18.70 \pm 0.83$ & $20.242 \pm 1.84$ \\
\hline & Total & $22.175 \pm 1.22$ & $20.759 \pm 2.38$ & \\
\hline \multirow{3}{*}{$\mathrm{CP}(\% \mathrm{DM})$} & 0 & $22.22 \pm 0.83$ & $21.73 \pm 0.48$ & $21.98 \pm 0.69$ \\
\hline & 20 & $21.17 \pm 0.51$ & $17.62 \pm 0.70$ & $19.37 \pm 1.92$ \\
\hline & Total & $21.67 \pm 0.87$ & $19.67 \pm 2.2$ & \\
\hline
\end{tabular}

${ }^{\mathrm{ns}}$ Non significant

\section{3. pH, aflatoxin content and Free Fatty Acid content of Fermented, Fortified and Protected Protein $(2 F 2 P)$ during storage.}

Degree of Acidity $(\mathrm{pH})$ as seen in Table 4, the tilapia $\mathrm{pH}$ on day 0 in the addition of turmeric and without turmeric was not significantly different and had an average of $4.35 \pm 0.04$ because the product is fermented which has an acidic $\mathrm{pH}$. Good silage could occur if the $\mathrm{pH}$ value of silage reaches less than 4.5. The $\mathrm{pH}$ value 20 days showed an increase when compared to day 0 , but the results were not significantly different and had an average of $5.09 \pm$ 0.05 . Long storage does not affect the decrease in $\mathrm{pH}$ [14].

Aflatoxin as seen in table 4 the addition of turmeric significantly affected $(<0.05)$ the aflatoxin contamination in $2 \mathrm{~F} 2 \mathrm{P}$ products, the addition of turmeric had aflatoxin contamination with an average of $53.67 \pm 4.60$ when compared to $33.19 \pm$ 1.05. Storage has a significant effect $(<0.05)$ on aflatoxin contamination in 2F2P feed. The addition of turmeric can reduce aflatoxin contamination higher by an average of 26.21 whereas, without turmeric 10.89 , this is because curcumin contains antibacterial and antioxidant properties.
Antioxidant content in turmeric can be a protection against oxidative damage that causes inhibition of free radical reactions due to lipid peroxidation. Lipid peroxidation is a cause of aflatoxin toxicity [15]. Phenol compounds in turmeric can form complexes with proteins and polysaccharides; as a result, curcumin can damage fungal cell walls [16].

The addition of turmeric to $2 \mathrm{~F} 2 \mathrm{P}$ affected the levels of FFA in a fermented feed $(<0.05)$ and had an average FFA lower of $8.72 \pm 0.46$ when compared to without turmeric $13.90 \pm 0.37$. Curcumin can inhibit or break the mechanism of the formation of free radicals in the auto-oxidation process in fat. [17] states that the addition of antioxidants to these lipids can inhibit oxidation reactions at the initiation and propagation stages. Antioxidants that form in the initiation and propagation reactions are relatively stable and do not have enough energy to be able to react with other lipid molecules to form new lipid radicals. Radicals formed will react with antioxidants to form non-radical products so that the free radicals contained in oil have decreased which can inhibit the increase in FFA. Result $\mathrm{pH}$, aflatoxin content and Free Fatty Acid content of Fermented, Fortified 
and Protected protein $(2 \mathrm{~F} 2 \mathrm{P})$ can be seen in Table

4.

Table 4. pH, aflatoxin content and Free Fatty Acid content of Fermented, Fortified and Protected Protein $(2 \mathrm{~F} 2 \mathrm{P})$ during storage.

\begin{tabular}{ccccc}
\hline Variabel & Storage time & \multicolumn{2}{c}{ Treatment } & \multirow{2}{*}{ Avarage } \\
\cline { 2 - 4 } & & Curcumin addition & Without Curcumin addition & $4.73 \pm 0.35$ \\
\multirow{3}{*}{$\mathrm{pH}^{\mathrm{ns}}$} & 0 & $4.38 \pm 0.02$ & $5.06 \pm 0.03$ & $4.72 \pm 0.42$ \\
& 20 & $4.32 \pm 0.03$ & $5.12 \pm 0.04$ & $40.57 \pm 15.27$ \\
\cline { 2 - 4 } Aflatoxin & Total & $4.38 \pm 0.02$ & $5.06 \pm 0.03$ & $27.74 \pm 8.51$ \\
\hline \multirow{3}{*}{ FFA } & 0 & $53.67 \pm 4.60$ & $27.46 \pm 6.83$ & $9.49 \pm 0.96$ \\
& 20 & $33.19 \pm 1.05$ & $22.30 \pm 9.55$ & $15.32 \pm 1.59$ \\
\hline & Total & $43.43 \pm 11.61$ & $24.88 \pm 7.95$ & $10.27 \pm 0.54$ \\
\hline
\end{tabular}

${ }^{\text {ns }}$ Non significant

\section{CONCLUSION}

The addition of $3 \%$ turmeric to $2 \mathrm{~F} 2 \mathrm{P}$ can maintain protein quality for 20 days so that it can maintain Chemical and physical quality (color, odor, taste, and texture), as well influence in reducing aflatoxin.

\section{REFERENCES}

[1] Hasan SAJ, Lokman IH, Saad AN, Zuki ABZ, Kassim AB. 2016. Research article effects of dietary supplementation of wet fermented feed with probiotic on the production performance of Akar Putra chicken. Asian J Poult Sci. 10:72-77.

[2] Alrawaiq, N. A., A. Abdullah. 2014. A review of antioxidant polyphenol curcumin and its role in detoxification. International Journal of PharmTech Research 6 (1): 280-289.

[3] Hall, C. 2001. Sources of Natural Antioxidant: OilSeed, Nuts, Legumes. Animal Product and Microbial Sources. P. 40.

[4] Falola, O, Alasa MC, Babayemi OJ. 2013. Assessment of silage quality and forage acceptability of vetiver grass (Chrysopogon zizanioides L Roberty) ensiled with cassava peels by wad goat. Pakistan J Nut. 12:529-533.

[5] Kung L., and R. Shaver. 2001. Interpretation and use silage fermentation analysis reports J. Focus on forage 13(3).

[6] Saun, R.J.V., and A.J. Heinrichs. 2008. Troubleshooting silage problems: How to identify potential problem. Proceedings of the Mid-Atlantic Conference: Pennsylvania, Penn state college. Pp 2-10.

\section{ACKNOWLEDGMENT}

The authors would like to thank to Universitas Gadjah Mada for financial support under the scheme of the Rekognisi Tugas Akhir (RTA) under the contract No.2129/UNI/DITLIT/DIT-

LIT/LT/2019

[7] Steele, E. 2004. Understanding and Measuring The Shelf-life of Food. Woodhead Publishing Limited. Abington.

[8] Pattaratanawadee, E., Rachtanapun, C., Wanchaitanawong, P., and Mahakarnchanakul. 2006. Antimicrobial activity of spice extracts against pathogenic and spoilage microorganisms. Kasetsart Journal: Natural Science. 40 (5): 159-165.

[9] Amagase, H., B.L. Betesch., H. Matsuura., S.S. Kasuga dan Y. Itakura. 2001. Intake of garlic and its bioactive component. J.Nutr. 131: 9558-9628.

[10] Amir, N. 2017. Peningkatan daya tahan dan mutu produk ikan kembung perempuan (Rastrelliger brachysoma) asin kering melalui penggunaan bumbu. Jurnal Jurusan Perikanan Faklutas Ilmu Kelautan dan Perikanan Universitas Hasanuddin. (8) $1:$ 4-5.

[11] Liu, J.Y., Lin, S.J., and Lin, J.K. 1993. Inhibitory effects of curcumin on protein kinase $\mathrm{C}$ activity induced by $12-\mathrm{O}-$ tetradecanoyl-13-acetate in NIH 3T3 cells.Carcinogenesis, 14(5), pp.857-6.

[12] Goel, A., A. B. Kunnumakkara dan B. B. Aggarwa. 2008. Curcumin as "curcumin": from kitchen to clinic. Biochemical Pharmacology. 75:787.

[13] Avika,D.R., Johan, A.E., dan Unggul.J.P. 2013. Pengaruh pemberian kunyit (curcuma domestica dalam 
mempertahankan kadar protein daging sapi yang menurun akibat radiasi. Jurusan Fisika Universitas Brawijaya, Malang. Jurnal, Vol. 2, No. 2.

[14] Ohshima, M., L. M. Cao., E. Kimura, and H. Yokota. 1997. Fermentasi quality of alfalfa and italian reygrass silase treated from both the herbages. Anim. Feed Sci. Technol. 68: 41-44.

[15] Galvano, F., A. Piva, A. Ritieni, and G. Galvano. 2001. Dietary strategies to counteract the effects of mycotoxins: A review. J.Food Prot. 64:120-131.
[16] Dhingra, O. D., Jham, G. N., Barcelos, R. C., Mendonca, F. A., \& Ghiviriga, I. (2007).Isolation and identification of the principal fungi toxic component of turmeric essential oil. Journal of Essential Oil Research, 19, 387-391.

[17] Adetola, D. A., D. D. Alabi, and O. A. Abdulrauf. 2016. Onvestigating storage duration and packaging materials on quality of fresh palm oil. Futa Journal of Research in Sciences, 12 (2): 252-259. 